Research article

Open Access

\title{
The functional loss of the retinoblastoma tumour suppressor is a common event in basal-like and luminal $B$ breast carcinomas
}

\author{
Jason I Herschkowitz ${ }^{1,2,4}$, Xiaping He ${ }^{1,2}$, Cheng Fan ${ }^{1}$ and Charles M Perou ${ }^{1,2,3}$
}

\author{
${ }^{1}$ Lineberger Comprehensive Cancer Center, University of North Carolina, Chapel Hill, NC 27599, USA \\ 2Department of Genetics, University of North Carolina, Chapel Hill, NC 27599, USA \\ 3Department of Pathology \& Laboratory Medicine, University of North Carolina, Chapel Hill, NC 27599, USA \\ ${ }^{4}$ Department of Molecular and Cellular Biology, Baylor College of Medicine, One Baylor Plaza, DeBakey M635, Houston, TX 77030, USA \\ Corresponding author: Charles M Perou, cperou@med.unc.edu
}

Received: 19 Jun 2008 Revisions requested: 31 Jul 2008 Revisions received: 22 Aug 2008 Accepted: 9 Sep 2008 Published: 9 Sep 2008

Breast Cancer Research 2008, 10:R75 (doi:10.1186/bcr2142)

This article is online at: http://breast-cancer-research.com/content/10/5/R75

(C) 2008 Herschkowitz et al.; licensee BioMed Central Ltd.

This is an open access article distributed under the terms of the Creative Commons Attribution License (http://creativecommons.org/licenses/by/2.0), which permits unrestricted use, distribution, and reproduction in any medium, provided the original work is properly cited.

\begin{abstract}
Introduction Breast cancers can be classified using whole genome expression into distinct subtypes that show differences in prognosis. One of these groups, the basal-like subtype, is poorly differentiated, highly metastatic, genomically unstable, and contains specific genetic alterations such as the loss of tumour protein 53 (TP53). The loss of the retinoblastoma tumour suppressor encoded by the RB1 locus is a well-characterised occurrence in many tumour types; however, its role in breast cancer is less clear with many reports demonstrating a loss of heterozygosity that does not correlate with a loss of RB1 protein expression.
\end{abstract}

Methods We used gene expression analysis for tumour subtyping and polymorphic markers located at the RB1 locus to assess the frequency of loss of heterozygosity in 88 primary human breast carcinomas and their normal tissue genomic DNA samples.
Results RB1 loss of heterozygosity was observed at an overall frequency of $39 \%$, with a high frequency in basal-like (72\%) and luminal B (62\%) tumours. These tumours also concurrently showed low expression of RB1 mRNA. p16 INK4a was highly expressed in basal-like tumours, presumably due to a previously reported feedback loop caused by RB1 loss. An RB1 loss of heterozygosity signature was developed and shown to be highly prognostic, and was potentially a predictive marker of response to neoadjuvant chemotherapy.

Conclusions These results suggest that the functional loss of $\mathrm{RB} 1$ is common in basal-like tumours, which may play a key role in dictating their aggressive biology and unique therapeutic responses.

\section{Introduction}

The retinoblastoma tumour suppressor gene (RB1) encodes a nuclear phosphoprotein that plays a central role in regulating the cell cycle [1]. Inactivation of both alleles of this gene is involved in the development of retinoblastoma, which is a rare childhood malignancy. The loss of RB1 is also a well-characterised occurrence in many other human tumour types and it is probable that the $\mathrm{p} 16^{\mathrm{INK} 4 a-C D K 4 / 6-R B}$ pathway is disrupted in most human tumours [2]. RB1 regulates progression through the G1 to S-phase transition of the cell cycle. In cells entering the cell cycle, extracellular signals induce the expression of D-type cyclins, which bind to and activate cyclin- dependent kinases (CDK4 and CDK6); these complexes in turn lead to the phosphorylation of RB and its dissociation from E2F family members that then transcriptionally activate many genes required for the S phase [1]. The INK4 family of CDK inhibitors (p16 INK4a, p15 INK4b, p18INK4c and p19INK4d) inhibits CDK4 and CDK6, retaining RB in its hypo-phosphorylated E2F-associated state, thereby preventing $\mathrm{G} 1$ to $\mathrm{S}$ phase progression. It has recently been shown that CDK4 and CDK6 (and CDK2) are dispensable for driving the essential cell cycle; however, they are required in specialised tissues and possibly to achieve higher levels of proliferation [3]. 
Inactivation of the RB1 gene in breast cancer was originally shown using a series of cell lines [4]. Subsequently, loss of heterozygosity ( $\mathrm{LOH}$ ) has been observed in primary tumours, but does not necessarily correlate with low RB1 protein expression as assessed by immunohistochemistry [5,6]. LOH has, however, been shown to correlate with low RB1 mRNA expression [5]. There are also genetic events upstream of RB1 that may be present in breast tumours, which can negatively impact RB1 function by promoting its phosphorylation, that include p16 INK4a loss [7] and cyclin D1 amplification/overexpression [8].

Breast cancer is a heterogeneous disease, which can be separated into clinically significant subtypes as defined by molecular profiling $[9,10]$. In addition to reproducible gene expression differences between these subtypes, specific molecular alterations continue to be identified that correlate with each subtype. Tumours of the basal-like subtype generally have a high mitotic index, tend to be p53 mutated [11] and highly express the proliferation signature, which is a gene cluster shown to contain many E2F target genes [12,13]. Here we report that $\mathrm{LOH}$ at the RB1 locus occurs at a high frequency in human basal-like and luminal $B$ tumours, while occurring infrequently in luminal $A$ and human epidermal growth factor receptor 2 (HER2)-enriched tumours. p16 INK4a is also highly expressed both by microarray and by immunohistochemistry in most of the RB1 LOH basal-like tumours, presumably due to a feedback caused by RB1 loss. These results further illustrate the unique biology of each breast cancer subtype.

\section{Materials and methods}

Patient samples and breast cancer microarray data sets

All human tumour samples were collected from fresh frozen primary breast tumours using protocols approved by the Institutional Review Board and were profiled as described previously using Agilent (Agilent Technologies, United States) oligo microarrays [9,14-16]. The primary microarray data for the 232 sample data set is available in the Gene Expression Omnibus (GEO) [GEO:GSE3165]. The data set containing only tumours with informative LOH status can be found in GEO [GEO:GSE10884], with 13 new samples in this study.

\section{DNA isolation and detection of RB1 loss of heterozygosity}

Patient DNA from lymphocytes, normal breast tissues and breast tumours was isolated using the DNeasy kit (Qiagen, Germany). We used two polymorphic markers; a variable number tandem repeat (VNTR) in intron 20 and D13S153; a microsatellite marker for RB1 LOH analyses. The primers were previously published for intron 20 [17]. The primers for D13S153 [AFM058xd6a, AFM058xd6m] were obtained from the Genome Data Bank (Johns Hopkins University, Baltimore, MD) [18]. The PCR products were run on the Agilent Bioanalyzer using DNA 1000 kit (Agilent, United States). The patient was called informative when there were two alleles present in their normal DNA. LOH was called when there was at least a $50 \%$ loss of an allele/band in the tumour for at least one of the two polymorphic markers.

\section{Statistical analysis}

The chi-square test and Fisher-Freeman-Halton exact test were used to examine correlations between RB1 LOH status, immunostaining and tumour subtype using SAS 9.1 (Cary, NC). An analysis of variance (ANOVA) and unpaired Student's $t$-test were performed and a box plot graph plotted to compare RB1 LOH status or immunostaining with gene expression using web based 'Statistics to Use' [19]. A Significance Analysis of Microarrays (SAM) was performed to identify genes that were significantly differentially expressed between tumours with RB1 LOH-positive tumours compared with $\mathrm{LOH}$ negative tumours [20]. Expression analysis systemic explorer was used to identify gene ontology categories overrepresented in the RB LOH gene list compared with the genes present on the array.

Whole genome RVista was used to determine the known transcription factor binding sites overrepresented in the $1 \mathrm{~kb}$ upstream region in the lists of genes examined compared with the rest of the RefSeq genes in the whole human genome [21]. Hypergeometric mean analysis was performed as described by Chung and colleagues [22]; this comparison gives the likelihood of finding co-occurrences between these gene sets by chance. The simulation was performed independently for each pair of gene sets analysed.

\section{Immunohistochemistry}

Formalin-fixed, paraffin-embedded tissue sections (approximately $5 \mu \mathrm{m}$ ) were processed using standard immunostaining methods. Following deparaffinisation in xylenes, slides were rehydrated through a graded series of alcohol and rinsed in PBS. Endogenous peroxidase activity was blocked with $3 \%$ hydrogen peroxidase. Samples were steamed for antigen retrieval with $10 \mathrm{mM}$ citrate buffer $(\mathrm{pH} \mathrm{6.0)}$ for 30 minutes. Slides were then incubated for 20 minutes with diluted normal blocking serum. The sections were incubated for 60 minutes at room temperature with primary antibody $\mathrm{pRb}$ (Visionbiosystems Novocastra, NCL-L-RB-358 clone 13A10, 1:50 dilution) or p16 (Santa Cruz, H-156, 1:50 dilution). The slides were incubated for 45 minutes with diluted biotinylated secondary antibody (1:250 dilution) and 30 minutes with Vectastain Elite ABC reagent (Vector Laboratories, United States). Sections were incubated in peroxidase substrate solution for visualisation. Slides were counterstained with haematoxylin and examined by light microscopy. Tumour immunoreactivity was scored as: $0=$ negative, $1=$ weak positive, $2=$ moderate positive and $3=$ strong positive. The evaluation of p16INK4a and RB1 protein staining was performed by two blinded independent researchers. 


\section{Results \\ Basal-like tumours show low expression of the RB1 transcript}

Tumours of the basal-like subtype have been shown in several studies to have a high mitotic rate and to highly express a proliferation gene signature $[11,12]$. For this reason, we postulated that there might be a defect in the RB pathway in these tumours. We first examined the expression levels of the core components and regulators of the RB pathway in a previously published microarray data set $[9,14]$ that contained 232 microarrays consisting of 184 primary breast tumour samples and nine normal breast samples (Figure 1). On average, RB1 was expressed at the lowest levels in basal-like tumours and at the highest levels in luminal A tumours (Figures 1 and 2a), while the converse was observed for the average expression of a previously defined proliferation gene signature [9] (Figure $2 b$ ). Tumours of the basal-like subtype also frequently showed high levels of $\mathrm{p} 16^{\mathrm{INK} 4 a}$ (Figures 1 and 2c) and E2F1 (Figure 1 and data not shown). Cyclin D1 levels, on the other hand, were elevated mainly in luminal tumours including noticeably higher expression in many luminal B tumours (Figures 1 and 2d); in addition, it was recently reported that there are often high level gains of the 11q13 locus that includes cyclin D1 in luminal tumours [23], therefore suggesting that cyclin D1 high expression can be considered a 'luminal event'. Similar findings concerning RB1 mRNA expression and the basal-like subtype have also recently been reported suggesting that this is a reproducible expression feature of basal-like tumours [24].

\section{LOH at the RB1 locus is associated with high proliferation rates and tumour subtype}

Due to the low expression of RB1 message in basal-like tumours we decided to examine these breast carcinomas for $\mathrm{LOH}$ at the RB1 locus. We investigated 88 paired primary human breast carcinomas and normal tissue genomic DNA samples to assess the frequency of $\mathrm{LOH}$ in RB1. We used two polymorphic markers located at the RB1 locus (13q14); a variable number tandem repeat (VNTR) in intron 20 and D13S153, that is a microsatellite marker located within intron 2. There were 67 cases that were informative for at least one of these two markers (see Figure $3 a$ as an example LOH). In total, 26 tumours showed RB1 LOH for at least one marker (26 of $67,38.8 \%$ ). This is consistent with the frequency of RB1 LOH seen in previous studies of breast cancer (26 to $47 \%)[5,6,25]$.

Next, using a previously defined proliferation gene signature [9], we clustered the gene expression data for this signature using just the $67 \mathrm{LOH}$ informative patients (Figure $3 \mathrm{~b}$ ). This analysis was able to sort the samples into two groups with the right most group containing most of the RB1 LOH positive

Figure 1
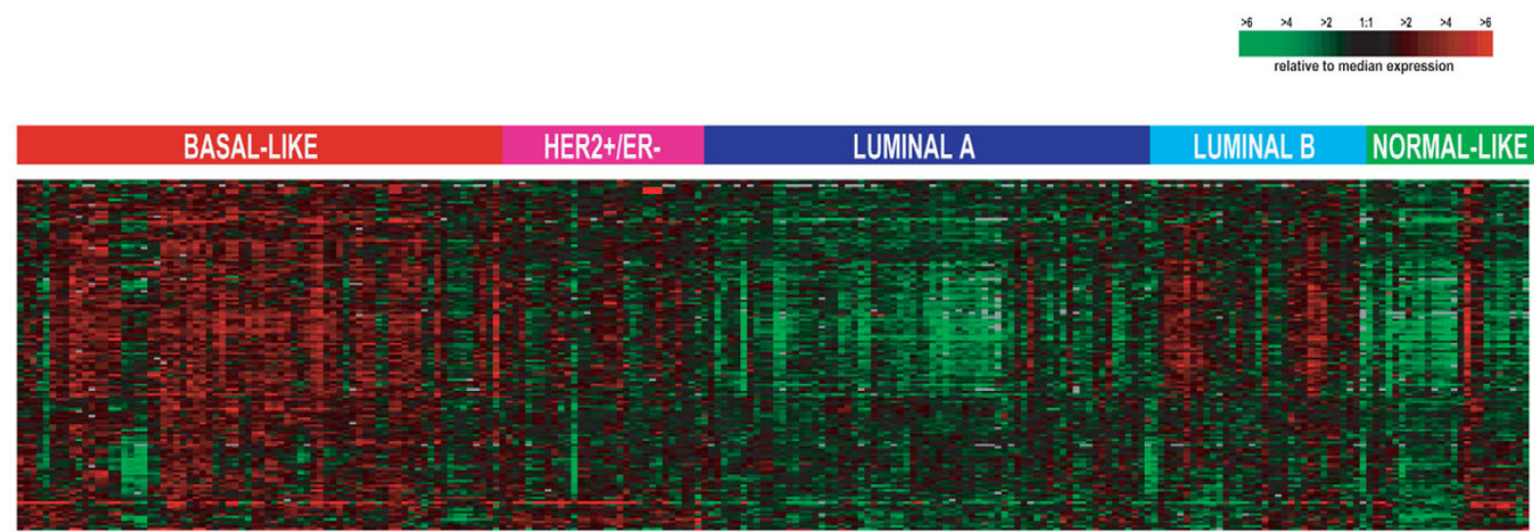

Proliferation

(b)

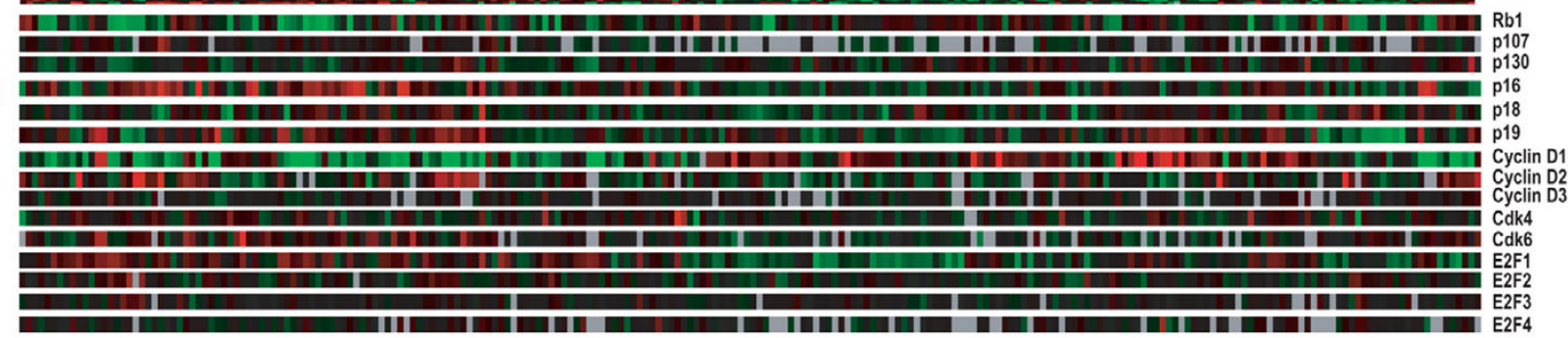

The expression of retinoblastoma pathway members varies across breast cancer intrinsic subtypes. Two-hundred and thirty-two human samples are ordered by subtype according to the five-class single sample predictor from Hu and colleagues [9]. Samples are coloured according to their subtype: red = basal-like, dark blue = luminal A, light blue = luminal B, pink = human epidermal growth factor receptor 2 (HER2)-enriched and green $=$ normal breast-like. (a) proliferation gene cluster. (b) Retinoblastoma (RB)-pathway genes which are present on the array and passed data quality filtering criteria of showing a signal intensity of more than 30 units in both channels. 
Figure 2

(a)

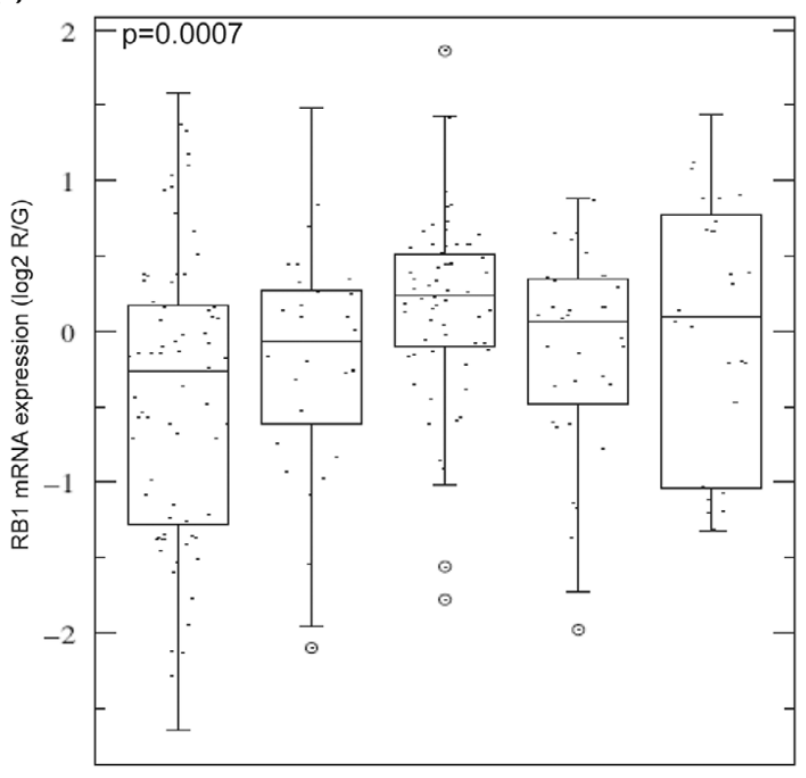

Basal Her2 LumA LumB Normal (b)

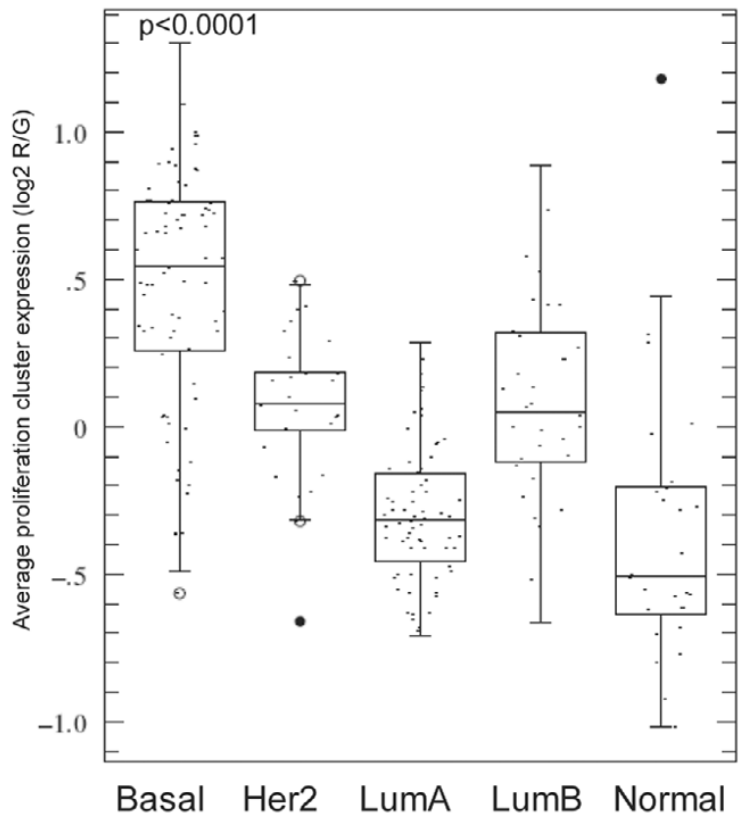

(c)

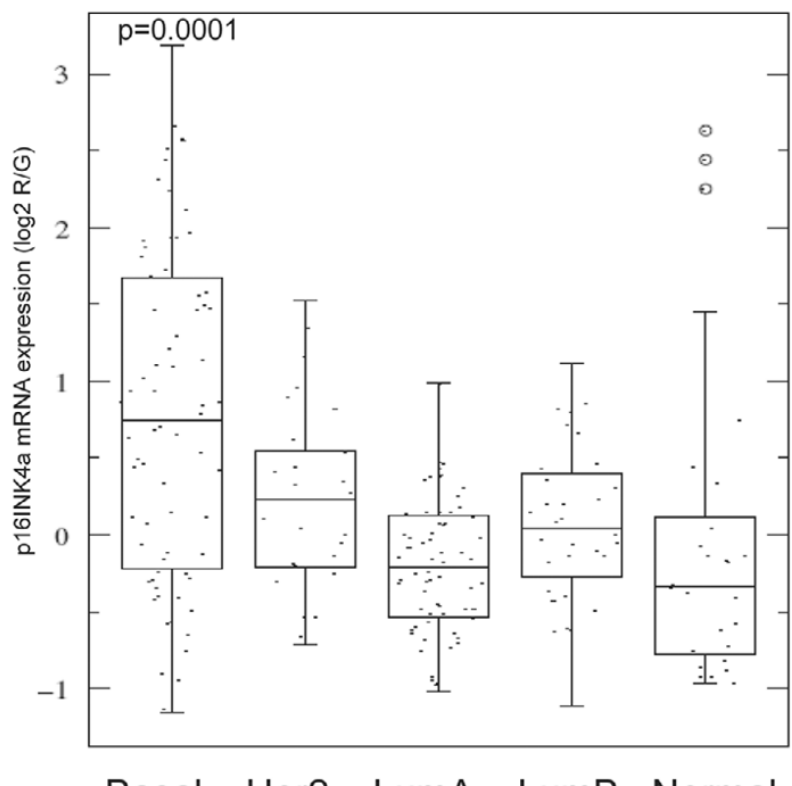

(d)

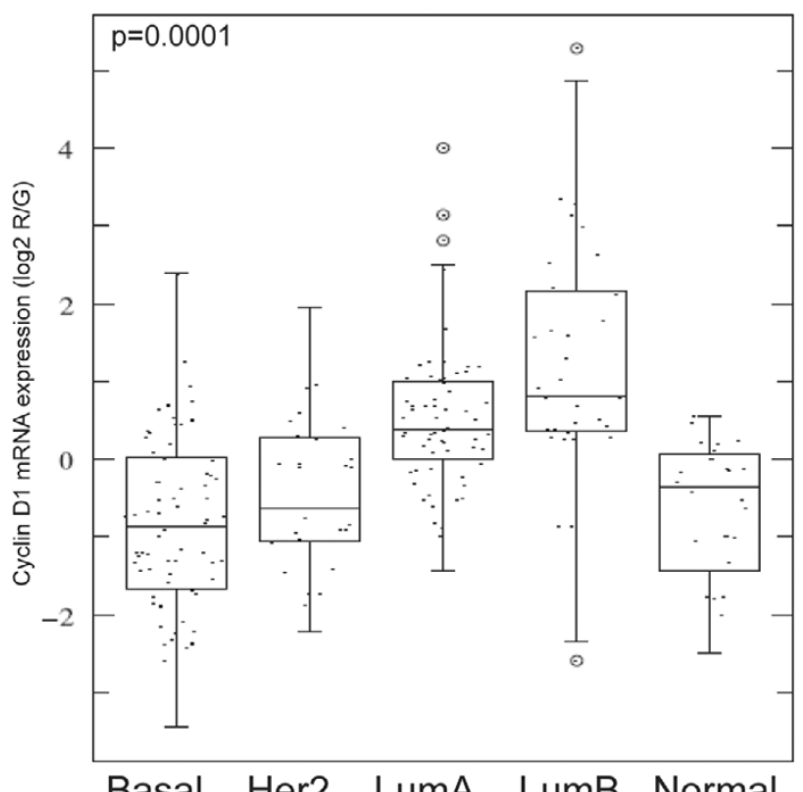

The expression of RB1, p16 INK4a and cyclin D1 varies across the breast cancer intrinsic subtypes. Box plot comparisons of (a) Retinoblastoma (RB) 1, (b) proliferation signature, (c) p16 ${ }^{\mathrm{INK}} \mathrm{a}$ and (d) cyclin D1 mRNA expression relative to the five intrinsic subtypes as defined by the five-class centroid predictor.

tumours ( 21 of $27,77.8 \%$ ). The left most group contained 29 of $40(72.5 \%)$ of the RB1 LOH-normal tumours. It is important to note, however, that many of the $\mathrm{LOH}$ positive tumours that did cluster in the left group were located on the outer nodes and still showed higher expression of the proliferation markers than the tumours in the centre. Overall, an ANOVA showed that RB1 LOH was highly correlated with the high expression of the proliferation gene cluster $(p=0.0001)$ (Figure 3c). 
(a)

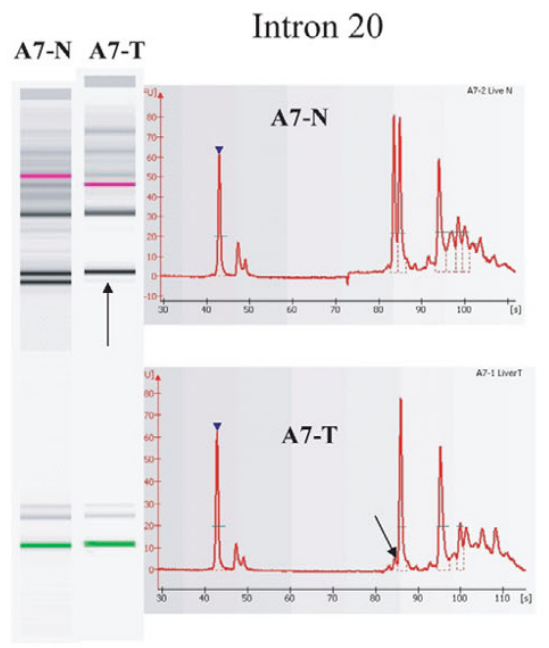

(b)

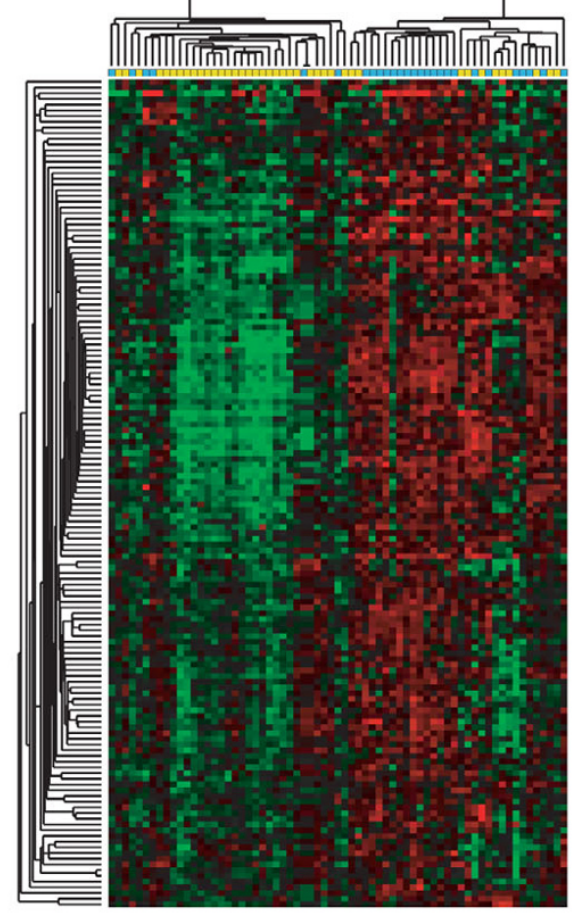

(c)

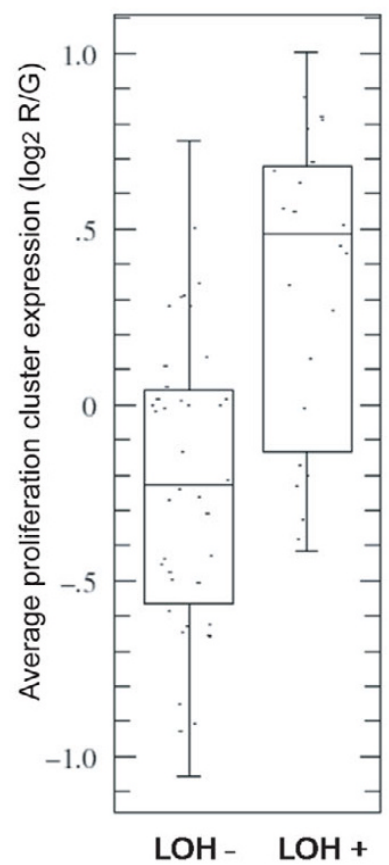

Retinoblastoma (RB) 1 loss of heterozygosity (LOH) is associated with high proliferation. (a) An example of LOH detected in a breast tumour sample at RB1 intron 20. The arrows point to the missing allele with A7-N being DNA from normal tissue and A7-T is tumour DNA from the same patient. (b) Two-way unsupervised hierarchical clustering of breast tumour samples with informative RB1 $\mathrm{LOH}$ status $(\mathrm{LOH}+=$ blue, $\mathrm{LOH}-=\mathrm{yel}-$ low) using the proliferation gene cluster. (c) Box plot comparison of the average proliferation cluster expression to RB1 LOH status.

We next classified the tumours that were assayed for RB1 $\mathrm{LOH}$ analysis according to intrinsic subtype using the fiveclass single sample predictor [9]. The frequency of RB1 LOH varied by molecular subtype $(p=0.0002)$ (Table 1$)$. The lowest $\mathrm{LOH}$ frequencies were observed in the luminal A ( 3 of 20 , $15 \%)$ and normal-like $(0$ of $7,0 \%)$ subtypes, while the HER2enriched subtype had a frequency near the breast cancer aver- age (3 of $9,33.3 \%)$. The highest frequency of RB1 LOH was observed in tumours of the basal-like (13 of $18,72.2 \%)$ and luminal $B$ subtypes ( 8 of $13,61.5 \%$ ), both of which are known to be highly proliferative tumour subtypes [9-11]. 
Subtype specificity of RB1 LOH and RB1 and p16iNK4a immunohistochemistry

\begin{tabular}{|c|c|c|c|c|c|c|c|}
\hline & Basal-like & HER2-enriched & Luminal A & Luminal B & Normal-like & Total & \\
\hline \multicolumn{8}{|l|}{ RB1 LOH } \\
\hline LOH positive & $13(48.2)$ & $3(11.1)$ & $3(11.1)$ & $8(29.6)$ & $0(0)$ & 27 & \\
\hline LOH negative & $5(12.5)$ & $6(15.0)$ & $17(42.5)$ & $5(12.5)$ & $7(17.5)$ & 40 & \\
\hline Total & 18 & 9 & 20 & 13 & 7 & 67 & $p=2.26 E-04$ \\
\hline \multicolumn{8}{|l|}{ RB IHC } \\
\hline 0 & $6(42.9)$ & $2(14.3)$ & $3(21.4)$ & $3(21.4)$ & $0(0)$ & 14 & \\
\hline $1+$ & $13(29.6)$ & $5(11.4)$ & $14(31.8)$ & $4(9.1)$ & $8(18.2)$ & 44 & \\
\hline $2+$ & $5(12.8)$ & $6(15.4)$ & $14(35.9)$ & $6(15.4)$ & $8(20.5)$ & 39 & \\
\hline $3+$ & $7(35.0)$ & $2(10.0)$ & $4(20.0)$ & 7 (35.0) & $0(0)$ & 20 & \\
\hline Total & 31 & 15 & 35 & 20 & 16 & 117 & $p=0.0644$ \\
\hline \multicolumn{8}{|l|}{ p16 IHC } \\
\hline 0 & $2(8.0)$ & $4(16.0)$ & $8(32.0)$ & $6(24.0)$ & $5(20.0)$ & 25 & \\
\hline $1+$ & $5(15.2)$ & $3(9.1)$ & $15(45.5)$ & $5(15.2)$ & $5(15.2)$ & 33 & \\
\hline $2+$ & $4(13.8)$ & $4(13.8)$ & $9(31.0)$ & $6(20.7)$ & $6(20.7)$ & 29 & \\
\hline $3+$ & $22(68.8)$ & $4(12.5)$ & $3(9.4)$ & $3(9.4)$ & $0(0)$ & 32 & \\
\hline Total & 33 & 15 & 35 & 20 & 16 & 119 & $p=1.41 E-05$ \\
\hline
\end{tabular}

$0=$ negative, $1+=$ weak positive, $2+=$ moderate positive, $3+=$ strong positive. $P$-values determined by Fisher's exact test.

HER2 = human epidermal growth factor receptor 2; IHC = immunohistochemistry; LOH = loss of heterozygosity; RB1 = retinoblastoma.

\section{RB1 and p16 INK4a immunostaining in breast carcinomas}

RB1 is expressed ubiquitously in mammary epithelial cells and typically shows a nuclear staining pattern in normal human breast tissue (Figure 4a). RB1 immunostaining was statistically correlated with RB1 message levels $(p=0.0081)$ but, as has been described before, RB1 protein expression did not correlate with RB1 LOH ( $p=0.5)$ [6]; however, a trend for low expression of RB1 message to occur with RB1 LOH was observed ( $p=0.11$ ). RB1 protein expression also tended to be low in basal-like tumours (Figure $4 \mathrm{~b}$ and Table 1), but this relationship was only near statistical significance $(p=0.064)$.

High p16 INK4a staining (3+), which is a hallmark of lost RB1 function [26,27], was seen in 32 of 119 tumours assayed and often included both nuclear and cytoplasmic staining (Figure 4c). p16 1 NK4a immunostaining was statistically correlated with p16 INK4a message levels ( $p=0.013$ ), especially when high staining was observed (data not shown). p16INK4a immunostaining was also associated with intrinsic tumour subtype ( $p=$ $1.41 \mathrm{E}-05)$ with 22 of $33(66.7 \%)$ of basal-like tumours showing $3+$ staining (Figure 4c, Table 1). The correlation between RB1 LOH status and $p 16^{\text {INK4a }}$ expression levels was statistically significant ( $p=0.01$ ) (Figure $4 d$, Table 2 ). In addition, p16 INK4a was similarly highly expressed in transgenic murine mammary tumours with loss of RB function driven by SV40 large T-antigen or T121 (Additional File 1) [14]. When considered together, these data suggest that RB1 LOH in basal-like tumours cause a loss of RB1 protein function, which the cells attempt to compensate for by increasing $\mathrm{p} 16^{\text {INK4a }}$ gene and protein expression levels.

\section{RB1 LOH gene expression signature}

To determine if there was a gene expression signature related to RB1 LOH, a two-class SAM [20] was performed of RB1 $\mathrm{LOH}$ positive tumours vs. $\mathrm{LOH}$-normal tumours. In total there were 452 genes that varied with RB1 $\mathrm{LOH}$ status with a false discovery rate of $0.94 \%$, as compared with 11 genes identified at a false discovery rate of $16.7 \%$ when a similar analysis was performed using RB immunostaining data (0 vs. 1, 2 and 3). Of these genes, 423 were highly expressed in tumours with $\mathrm{RB} 1 \mathrm{LOH}$ and an analysis of the gene ontologies associated with this gene set showed that cell cycle, cell division, DNA metabolism, spindle organisation and biogenesis, and response to DNA damage were the top biological processes discovered when using Bonferroni-corrected scores. Interestingly, E2F1, E2F3 and E2F5 were present on this supervised gene list and highly expressed in tumours with RB1 LOH. Also present in this list was RB1CC1, a regulator of RB1 expression that has been shown to contain truncating mutations in breast cancers [28]. We used whole genome RVista to calcu- 



(d)

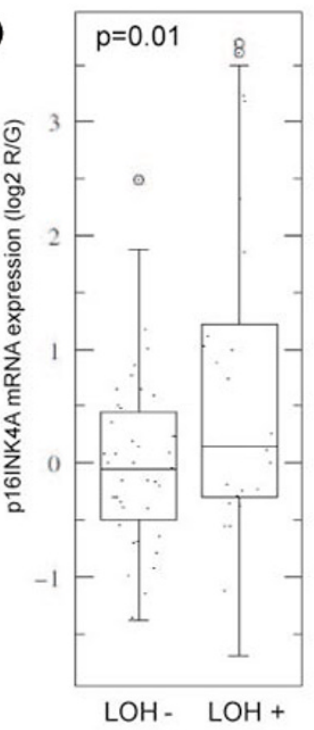

High p16INK4a mRNA and protein levels are associated with retinoblastoma (RB) 1 loss of heterozygosity (LOH). (a) RB1 staining of normal breast tissue, (b) RB1 LOH+ basal-like tumour lacking RB1 staining, and (c) the same RB1 LOH+ basal-like tumour showing staining for p16INK4a both nuclear and cytoplasmic.(d) Box plot comparison showing high p16 INK4a mRNA expression in RB1 LOH + breast tumours.

late which transcription factor binding sites might be present within the 1000 bp upstream regions of these genes [21] and determined that the top three transcription factor binding sites with $p<0.005$ were E2F4:DP1, E2F1:DP1:RB and E2F4:DP2, showing that a majority of these genes are likely to be E2F-regulated; other statistically significant transcription factor binding sites were HIF1:ARHN. Only 29 genes were significantly negatively/downregulated from the RB1 LOH
SAM analysis, and there were no significant gene ontology categories enriched in this list.

\section{RB1 LOH gene expression signature correlates with signatures of proliferation and RB-loss}

Recently, an RB-loss gene expression signature was derived using mouse fibroblasts with either acute or chronic knockout of RB1 using conventional knockout as well as Cre-Lox technology [29]. As might be expected, this RB-loss signature was 
Table 2

Comparison of p16INK4a immunohistochemistry and RB1 LOH status

\begin{tabular}{|c|c|c|c|c|c|c|}
\hline & p16 IHC 0 & $1+$ & $2+$ & $3+$ & Total & \\
\hline \multicolumn{7}{|l|}{ RB1 LOH } \\
\hline LOH- & $9(23.7)$ & $11(29.0)$ & $11(29.0)$ & $7(18.4)$ & 38 & \\
\hline \multirow[t]{2}{*}{ LOH+ } & 1 (3.9) & $8(30.8)$ & $5(19.2)$ & $12(46.2)$ & 26 & \\
\hline & 10 & 19 & 16 & 19 & 64 & $p=0.0369$ \\
\hline
\end{tabular}

$0=$ negative, $1+=$ weak positive, $2+=$ moderate positive, $3+=$ strong positive. $P$-values determined by Chi-square test.

$\mathrm{IHC}=$ immunohistochemistry; $\mathrm{LOH}=$ loss of heterozygosity; $\mathrm{RB} 1$ = retinoblastoma.

highly expressed in basal-like tumours (Additional File 2). This RB-loss signature significantly overlapped with the proliferation signature (29 of 139 genes of the RB-loss signature are contained in the 140 gene human proliferation signature used here, hypergeometric mean $p<0.001$ ), thus serving as further evidence that the proliferation signature contains many RB1E2F regulated genes. There was statistically significant overlap among all three RB-pathway signatures studied here (ie, RB-LOH, RB-loss and proliferation) as determined by hypergeometric mean analysis $p<0.001$, and thus all three signatures are probably tracking a common biology that is RB1-E2F dependent. There were 20 genes that overlapped between all three gene lists (Figure 5), which included cell cycle-related genes including the spindle assembly checkpoint proteins BUB1 and MAD2, and many commonly used chemotherapeutic drug targets including TOP2A (doxorubicin, etoposide), thymidylate synthetase (5-FU), ribonucleotide reductase M2 (hydroxyurea) and CDC2 (flavopiridol, staurosporine).

All four of these RB-pathway associated lists (RB-LOH, RBloss, proliferation signature and the 20 common genes) were highly predictive of breast cancer patient outcomes when using a two-class or three-class, average value rank order expression cutoff and when tested on the NKI295 patient data set (Figure 6, shown using RB-LOH list and data not shown for the other three lists that give very similar results) [30], and on a previously described 251 patient data set (data not shown) [31]. It should be noted, however, that several groups have independently identified different gene lists that contain a large number of so-called proliferation/RB-pathway genes $[13,32-35]$ and it was expected that the RB-LOH signature would be a strong prognostic profile.

The RB-pathway associated signatures were predictive of poor prognosis in breast cancers. But are they predictive of response to therapy? To answer this question, we determined if the RB-LOH signature correlated with pathological complete response in a well-annotated data set of neoadjuvant chemotherapy-treated patients [36]. The study by Hess and colleagues included 133 patients with stage I to III breast cancer that were treated with preoperative weekly paclitaxel followed by fluorouracil-doxorubicin-cyclophosphamide chemotherapy. High expression of each of the four RB-pathway signatures was associated with pathological complete response in the breast and regional lymph nodes (Additional File 3). Thus, high expression of the RB-LOH and proliferation signatures is associated with a good response to neoadjuvant chemotherapy in breast cancers.

Figure 5

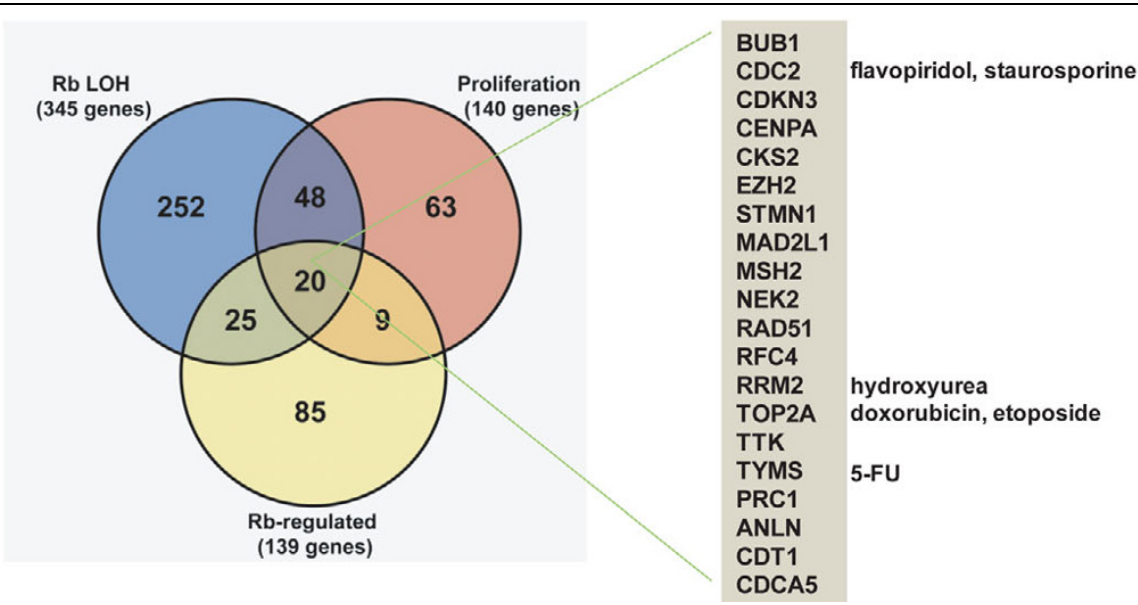

Venn diagram showing the overlap between the retinoblastoma (RB) 1 loss of heterozygosity (LOH), proliferation, and RB1-loss gene lists. 
Figure 6
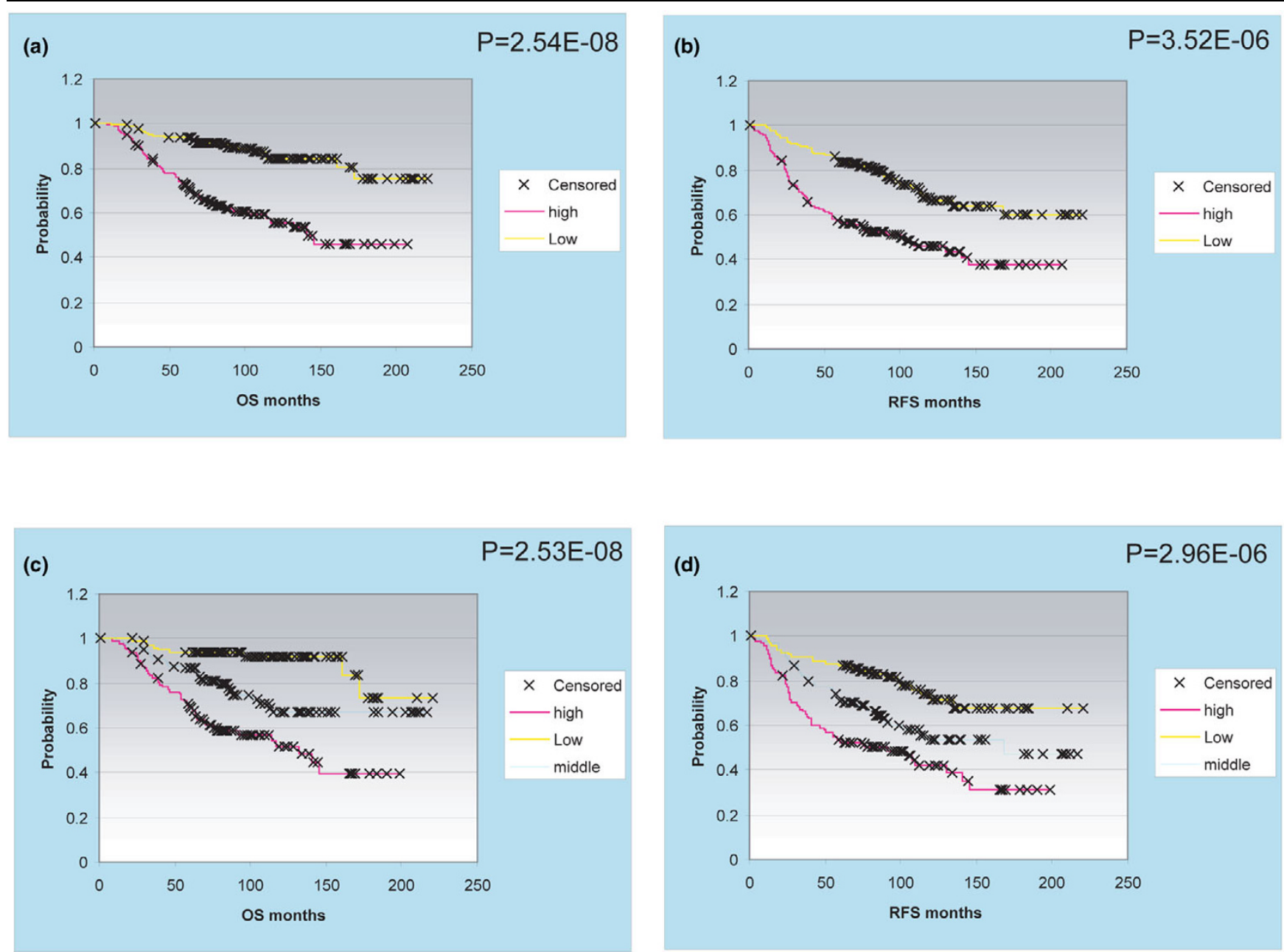

Retinoblastoma (RB) 1 loss of heterozygosity (LOH) gene list is highly predictive of breast cancer patient outcome. Kaplan-Meier survival curves showing overall survival (OS) or relapse-free survival (RFS) by dividing the patients in thirds $(a, c)$ or in halves (b, d) using the rank order average expression values of the RB-LOH signature using the NKI295 breast cancer data set.

\section{Discussion}

Our understanding of breast cancer biology has been improved by the identification of genomically defined tumour subtypes. These subtypes are defined by distinct gene expression patterns, molecular changes and potentially distinct developmental cell types of origin adding up to observed differences in outcome and responses to therapy. In this report, we show that the frequency of RB1 LOH varied significantly according to 'intrinsic' subtype. RB1 LOH occurs at a frequency of $72.2 \%$ in basal-like breast tumours and $61.5 \%$ in luminal $B$ tumours, both of which are observed in retinoblastomas in the frequency range of 60 to $75 \%$ [37-40]. RB1 protein staining as assessed by immunohistochemistry, however, did not correlate with RB1 LOH in our study (as has been reported before); however, a SAM analysis supervised by RB1 $\mathrm{LOH}$ robustly identified many E2F genes, and E2F-regulated target genes, while the RB1 protein-guided SAM analysis did not. This suggests that RB1 LOH is a better biomarker of RB- pathway function than immunohistochemistry staining for total RB1 protein.

Additional support for the functional loss of RB1 in basal-like tumours comes from the correlation with high $\mathrm{p} 16^{\text {INK4a }}$ message and protein expression. The inverse relationship between p16 INK4a and RB1 expression in breast cancers has been previously reported $[41,42]$; however, this relationship and its association with basal-like tumours is new in this report. Another intriguing link between p16 INK4a and basal-like cells comes from studies on human mammary epithelial cells, which have been shown to resemble the basal-like subtype by gene expression analysis $[43,44]$. It has been shown that in order for human mammary epithelial cells to proliferate in vitro in culture for an extended period they must overcome an RB-mediated stress associated senescence barrier (stasis), which usually involves spontaneously losing p16 INK4a expression by promoter methylation [45]. The gene expression changes associ- 
ated with this in vitro transition are similar to those we previously reported to occur with RB1 LOH [46].

In basal-like tumours in vivo, however, the exact opposite seems to occur in that the RB-pathway barrier appears to be RB1 functional loss with a concomitant feedback loop that induces $\mathrm{p} 16^{\mathrm{INK} 4 \mathrm{a}}$ gene and protein expression. The link between high p16INK4a expression being caused by RB1 loss is known; RB1 recruits Polycomb repression complexes to the p16INK4a locus, which silence p16 INK4a transcription [47]. It is also well-known that cell cycle inhibition by p16 INK4a is RBdependent [48] and, therefore, these RB1-deficient breast tumours would be expected to be refractory to the high levels of $\mathrm{p} 16^{\mathrm{INK} 4 a}$. This explains their high proliferation rates in the presence of high levels of $\mathrm{p} 16^{\mathrm{INK} 4 a}$. High p16 1 INK4a expression has reproducibly been shown to be associated with poor prognosis [41,49-51] and in a recent study by Grupka and colleagues, p16 INK4a staining of sentinel lymph nodes was predictive in determining the presence of non-sentinel node metastases [52]. Gauthier and colleagues have recently shown that in ductal carcinoma in situ (DCIS) lesions, high p16INK4a together with low Ki-67 (proliferation) appears to not promote tumour progression, while high $\mathrm{p} 16^{\mathrm{INK} 4 \mathrm{a}}$ and high Ki67 lead to subsequent tumours [24]. Lastly, it has been demonstrated that the deletion of RB1 in the murine mammary gland is capable of initiating tumourigenesis and that many of these resulting tumours have basal-like features (E. Zacksenhaus, personal communication). In total, these data strongly argue that the RB-pathway lesion that occurs in most basallike tumours is RB1 loss, possibly with a compensatory activation of $\mathrm{p} 16^{\mathrm{INK} 4 \mathrm{a}}$.

Basal-like tumours also highly express a recently published RB-loss gene expression signature [29,32], which we have shown to have significant similarity to a previously defined proliferation signature and our newly described RB1 LOH signature. Lastly, the p16INK4a expression seen in DCIS by Gauthier and colleagues, and the elevated $\mathrm{Ki}-67$ index seen in basal-like DCIS lesions, suggests that RB1 loss may be an early event for this tumour type [53].

Similar to basal-like tumours, luminal B tumours also showed a high frequency $(61.5 \%)$ of RB1 LOH in our study, but this was not associated with induction of $\mathrm{p} 16^{\mathrm{INK} 4 a}$. The differential effect of RB1 loss on p16 ${ }^{\text {INK4a }}$ expression in luminal B versus basal-like tumour cells implicates other transcription factors in addition to $\mathrm{pRb}-\mathrm{E} 2 \mathrm{~F}$ in the regulation of this CDK inhibitor in luminal tumours. In the recent study by Bosco and colleagues, luminal tumour-derived cell lines were shown to be more proliferative and resistant to hormone therapy after knockdown of RB1 [32], both of which are signatures of luminal B tumours [9-11]. The RB-loss signature was shown to be predictive of outcome in a data set containing only oestrogen receptor positive (ER+) breast tumours treated with tamoxifen monotherapy. Therefore, the loss of RB1 function may also play a substantial role in the increased proliferation, possible resistance to hormonal therapies and poor prognosis that is seen in luminal B tumours. In addition, the knockdown of RB1 in established breast cancer cell lines has recently been shown to increase sensitivity to a variety of DNA-damaging therapeutic agents [32,54]. While these experiments were performed with ER+ tumour cell lines, it does open the possibility that the RB1-defect in basal-like tumours plays a role in their increased chemosensitivity compared with most luminal tumours $[55,56]$. This is supported by our findings of increased neoadjuvant response in patients expressing high levels of the four different RB1-proliferation associated signatures.

The presence of $\mathrm{LOH}$ is typically thought to indicate that a mutated allele is present on the other chromosome and that the LOH makes the cell homozygous or hemizygous for the mutated allele. There is little published evidence to suggest that dramatic structural changes aside from $\mathrm{LOH}$ are occurring at the RB1 locus in breast tumours. There are a few reports of alterations in RB1 in breast cancer with two reports showing structural changes as assessed by Southern blotting in $7 \%$ and $19 \%$ of primary tumours [57,58], and no published reports to our knowledge of point mutations. Interestingly, a study by Kallioniemi and colleagues looking at RB1 loss in clinical breast cancer samples by fluorescent in situ hybridisation showed that most of the cells within these tumours contained two copies of the RB1 gene even when they showed LOH by restriction fragment length polymorphism at the RB1 locus [59]. When these studies are considered with the data presented here, they suggest a complex scenario where one allele is lost by $\mathrm{LOH}$ and the remaining allele/residual protein is compromised by an as yet to be identified mechanism(s) that potentially varies between tumour subtype, and potentially varies even within basal-like tumours. For example, some basallike tumours with $\mathrm{LOH}$ show complete loss of RB protein, while others show expression and both types show high proliferation. As opposed to breast cancer, there is a great deal known about the mechanisms of RB1 loss in retinoblastoma [60-62]. As in retinoblastoma, it is clear that a combination of techniques will need to be applied in order to identify the precise mechanisms of RB1 inactivation in breast cancer.

\section{Conclusion}

We have shown that RB1 $\mathrm{LOH}$ is a frequent occurrence in basal-like and luminal $B$ breast tumours and is associated with deregulation of E2F-regulated genes. Deregulation of the RBpathway in cell lines has shown that it may be an important determinant of response to therapy [32]. Moreover, we have demonstrated that RB1 loss signatures can be used to predict neoadjuvant chemotherapy response. Therefore, RB1 function may be an important biomarker for informing treatment decisions. 


\section{Competing interests}

CMP has stock ownership in University Genomics. Other authors declare no competing interests.

\section{Authors' contributions}

$\mathrm{JIH}$ participated in the data analysis, scoring of immunohistochemistry staining, development of the figures and the writing of the manuscript. $\mathrm{XH}$ prepared DNA from tumours and normal patient lymphocytes, and immunohistochemistry staining and scoring. CF performed statistical analysis. CMP was the principal investigator, conceived and designed the study, and drafted the paper. All authors read and approved the final manuscript.

\section{Additional files}

The following Additional files are available online:

\section{Additional File 1}

A PDF file containing a figure comparing $\mathrm{p} 16^{\mathrm{INK} 4 \mathrm{a}}$ and proliferation gene expression across 13 transgenic murine mammary tumour models.

See http://www.biomedcentral.com/content/

supplementary/bcr2142-S1.pdf

\section{Additional File 2}

A PDF file containing a figure showing a box plot comparison of RB-loss signature relative to the five intrinsic subtypes as defined by the 5 -class centroid predictor.

See http://www.biomedcentral.com/content/

supplementary/bcr2142-S2.pdf

\section{Additional File 3}

A PDF file containing a figure showing a box plot comparison of average expression of a) RB-LOH, b) RB loss, c) proliferation signature and d) 20-gene overlap signature relative to response to neoadjuvant treatment. See http://www.biomedcentral.com/content/ supplementary/bcr2142-S3.pdf

\section{Acknowledgements}

We thank Yue Xiong and Ned Sharpless for comments and reviews of this manuscript. This work was supported by funds from the $\mathrm{NCl}$ Breast SPORE program to UNC-CH (P50-CA58223-09A1), by RO1-CA101227-01, the V Foundation for Cancer Research and by the Breast Cancer Research Foundation.

\section{References}

1. Weinberg RA: The retinoblastoma protein and cell cycle control. Cell 1995, 81:323-330.

2. Sherr CJ: Cancer cell cycles. Science 1996, 274:1672-1677.

3. Santamaria D, Barriere C, Cerqueira A, Hunt S, Tardy C, Newton K, Caceres JF, Dubus P, Malumbres M, Barbacid M: Cdk1 is sufficient to drive the mammalian cell cycle. Nature 2007, 448:811-815.
4. Lee EY, To H, Shew JY, Bookstein R, Scully P, Lee WH: Inactivation of the retinoblastoma susceptibility gene in human breast cancers. Science 1988, 241:218-221.

5. Bieche I, Lidereau R: Loss of heterozygosity at $13 q 14$ correlates with RB1 gene underexpression in human breast cancer. $\mathrm{Mol}$ Carcinog 2000, 29:151-158.

6. Borg A, Zhang QX, Alm P, Olsson H, Sellberg G: The retinoblastoma gene in breast cancer: allele loss is not correlated with loss of gene protein expression. Cancer Res 1992, 52:2991-2994.

7. Geradts J, Wilson PA: High frequency of aberrant p16(INK4A) expression in human breast cancer. Am J Pathol 1996, 149:15-20.

8. Buckley MF, Sweeney KJ, Hamilton JA, Sini RL, Manning DL, Nicholson RI, deFazio A, Watts CK, Musgrove EA, Sutherland RL: Expression and amplification of cyclin genes in human breast cancer. Oncogene 1993, 8:2127-2133.

9. Hu Z, Fan C, Oh DS, Marron JS, He X, Qaqish BF, Livasy C, Carey LA, Reynolds E, Dressler L, Nobel A, Parker J, Ewend ME, Sawyer LR, Wu J, Liu Y, Nanda R, Tretiakova M, Ruiz Orrico A, Dreher D, Palazzo JP, Perreard L, Nelson E, Mone M, Hansen H, Mullins M, Quackenbush JF, Ellis MJ, Olopade OI, Bernard PS, et al.: The molecular portraits of breast tumors are conserved across microarray platforms. BMC Genomics 2006, 7:96.

10. Sorlie T, Tibshirani R, Parker J, Hastie T, Marron JS, Nobel A, Deng S, Johnsen H, Pesich R, Geisler S, Demeter J, Perou CM, Lonning $\mathrm{PE}$, Brown PO, Borresen-Dale AL, Botstein D: Repeated observation of breast tumor subtypes in independent gene expression data sets. Proc Natl Acad Sci USA 2003, 100:8418-8423.

11. Sorlie T, Perou CM, Tibshirani R, Aas T, Geisler S, Johnsen H, Hastie T, Eisen MB, Rijn M van de, Jeffrey SS, Thorsen T, Quist $H$, Matese JC, Brown PO, Botstein D, Eystein Lonning P, BorresenDale AL: Gene expression patterns of breast carcinomas distinguish tumor subclasses with clinical implications. Proc Natl Acad Sci USA 2001, 98:10869-10874.

12. Livasy CA, Karaca G, Nanda R, Tretiakova MS, Olopade OI, Moore DT, Perou CM: Phenotypic evaluation of the basal-like subtype of invasive breast carcinoma. Mod Pathol 2006, 19:264-71.

13. Whitfield ML, George LK, Grant GD, Perou CM: Common markers of proliferation. Nat Rev Cancer 2006, 6:99-106.

14. Herschkowitz JI, Simin K, Weigman VJ, Mikaelian I, Usary J, Hu Z, Rasmussen KE, Jones LP, Assefnia S, Chandrasekharan S, Backlund MG, Yin Y, Khramtsov Al, Bastein R, Quackenbush J, Glazer RI, Brown PH, Green JE, Kopelovich L, Furth PA, Palazzo JP, Olopade OI, Bernard PS, Churchill GA, Van Dyke T, Perou CM: Identification of conserved gene expression features between murine mammary carcinoma models and human breast tumors. Genome Biol 2007, 8:R76.

15. Oh DS, Troester MA, Usary J, Hu Z, He X, Fan C, Wu J, Carey LA, Perou CM: Estrogen-Regulated Genes Predict Survival in Hormone Receptor-Positive Breast Cancers. J Clin Oncol 2006, 24:1656-64

16. Weigelt B, Hu Z, He X, Livasy C, Carey LA, Ewend MG, Glas AM, Perou CM, Van't Veer LJ: Molecular portraits and 70-gene prognosis signature are preserved throughout the metastatic process of breast cancer. Cancer Res 2005, 65:9155-9158.

17. Semczuk A, Marzec B, Roessner A, Jakowicki JA, Wojcierowski J, Schneider-Stock R: Loss of heterozygosity of the retinoblastoma gene is correlated with the altered $\mathrm{pRb}$ expression in human endometrial cancer. Virchows Arch 2002, 441:577-583.

18. Genome Data Bank [http://www.gdb.org/]

19. Statistics to Use [http://www.physics.csbsju.edu/stats/]

20. Tusher VG, Tibshirani R, Chu G: Significance analysis of microarrays applied to the ionizing radiation response. Proc Natl Acad Sci USA 2001, 98:5116-5121.

21. Zambon AC, Zhang L, Minovitsky S, Kanter JR, Prabhakar S, Salomonis N, Vranizan K, Dubchak I, Conklin BR, Insel PA: Gene expression patterns define key transcriptional events in cellcycle regulation by cAMP and protein kinase A. Proc Natl Acad Sci USA 2005, 102:8561-8566.

22. Chung CH, Parker JS, Karaca G, Wu J, Funkhouser WK, Moore D, Butterfoss D, Xiang D, Zanation A, Yin X, Shockley WW, Weissler MC, Dressler LG, Shores CG, Yarbrough WG, Perou CM: Molecular classification of head and neck squamous cell carcinomas using patterns of gene expression. Cancer Cell 2004 5:489-500. 
23. Chin K, DeVries S, Fridlyand J, Spellman PT, Roydasgupta R, Kuo WL, Lapuk A, Neve RM, Qian Z, Ryder T, Chen F, Feiler H, Tokuyasu T, Kingsley C, Dairkee S, Meng Z, Chew K, Pinkel D, Jain A, Ljung BM, Esserman L, Albertson DG, Waldman FM, Gray JW: Genomic and transcriptional aberrations linked to breast cancer pathophysiologies. Cancer Cell 2006, 10:529-541.

24. Gauthier ML, Berman HK, Miller C, Kozakeiwicz K, Chew K, Moore D, Rabban J, Chen YY, Kerlikowske K, Tlsty TD: Abrogated response to cellular stress identifies DCIS associated with subsequent tumor events and defines basal-like breast tumors. Cancer Cell 2007, 12:479-491.

25. Wang ZC, Lin M, Wei L, Li C, Miron A, Lodeiro G, Harris L, Ramaswamy S, Tanenbaum DM, Meyerson M, Iglehart JD, Richardson A: Loss of heterozygosity and its correlation with expression profiles in subclasses of invasive breast cancers. Cancer Res 2004, 64:64-71.

26. Li Y, Nichols MA, Shay JW, Xiong Y: Transcriptional repression of the D-type cyclin-dependent kinase inhibitor p16 by the retinoblastoma susceptibility gene product $\mathbf{p R b}$. Cancer Res 1994, 54:6078-6082.

27. Tam SW, Shay JW, Pagano M: Differential expression and cell cycle regulation of the cyclin-dependent kinase 4 inhibitor p16Ink4. Cancer Res 1994, 54:5816-5820.

28. Chano T, Kontani K, Teramoto K, Okabe H, lkegawa S: Truncating mutations of RB1CC1 in human breast cancer. Nat Genet 2002, 31:285-288

29. Markey MP, Bergseid J, Bosco EE, Stengel K, Xu H, Mayhew CN, Schwemberger SJ, Braden WA, Jiang Y, Babcock GF, Jegga AG, Aronow BJ, Reed MF, Wang JY, Knudsen ES: Loss of the retinoblastoma tumor suppressor: differential action on transcriptional programs related to cell cycle control and immune function. Oncogene 2007, 26:6307-18

30. Vijver MJ van de, He YD, van't Veer LJ, Dai H, Hart AA, Voskuil DW, Schreiber GJ, Peterse JL, Roberts C, Marton MJ, Parrish M, Atsma D, Witteveen A, Glas A, Delahaye L, Velde T van der, Bartelink H, Rodenhuis S, Rutgers ET, Friend SH, Bernards R: A geneexpression signature as a predictor of survival in breast cancer. N Engl J Med 2002, 347:1999-2009.

31. Miller LD, Smeds J, George J, Vega VB, Vergara L, Ploner A, Pawitan $Y$, Hall $P$, Klaar S, Liu ET, Bergh J: An expression signature for p53 status in human breast cancer predicts mutation status, transcriptional effects, and patient survival. Proc Natl Acad Sci USA 2005, 102:13550-13555.

32. Bosco EE, Wang Y, Xu H, Zilfou JT, Knudsen KE, Aronow BJ, Lowe SW, Knudsen ES: The retinoblastoma tumor suppressor modifies the therapeutic response of breast cancer. J Clin Invest 2007, 117:218-228.

33. Dai H, van't Veer L, Lamb J, He YD, Mao M, Fine BM, Bernards R, van de Vijver MJ van de, Deutsch $P$, Sachs A, Stoughton R, Friend $\mathrm{SH}$ : A cell proliferation signature is a marker of extremely poor outcome in a subpopulation of breast cancer patients. Cancer Res 2005, 65:4059-4066.

34. Paik S, Shak S, Tang G, Kim C, Baker J, Cronin M, Baehner FL, Walker MG, Watson D, Park T, Hiller W, Fisher ER, Wickerham $\mathrm{DL}$, Bryant J, Wolmark N: A multigene assay to predict recurrence of tamoxifen-treated, node-negative breast cancer. $N$ Engl J Med 2004, 351:2817-2826.

35. Perreard L, Fan C, Quackenbush JF, Mullins M, Gauthier NP, Nelson $\mathrm{E}$, Mone M, Hansen $\mathrm{H}$, Buys SS, Rasmussen $\mathrm{K}$, Orrico AR, Dreher D, Walters R, Parker J, Hu Z, He X, Palazzo JP, Olopade OI, Szabo A, Perou CM, Bernard PS: Classification and risk stratification of invasive breast carcinomas using a real-time quantitative RT-PCR assay. Breast Cancer Res 2006, 8:R23.

36. Hess KR, Anderson K, Symmans WF, Valero V, Ibrahim N, Mejia JA, Booser D, Theriault RL, Buzdar AU, Dempsey PJ, Rouzier R, Sneige N, Ross JS, Vidaurre T, Gomez HL, Hortobagyi GN, Pusztai $\mathrm{L}$ : Pharmacogenomic predictor of sensitivity to preoperative chemotherapy with paclitaxel and fluorouracil, doxorubicin, and cyclophosphamide in breast cancer. J Clin Oncol 2006, 24:4236-4244.

37. Choy KW, Pang CP, Yu CB, Wong HL, Ng JS, Fan DS, Lo KW, Chai JT, Wang J, Fu W, Lam DS: Loss of heterozygosity and mutations are the major mechanisms of RB1 gene inactivation in Chinese with sporadic retinoblastoma. Hum Mutat 2002, 20:408.

38. Hagstrom SA, Dryja TP: Mitotic recombination map of 13cen$13 q 14$ derived from an investigation of loss of heterozygosity in retinoblastomas. Proc Natl Acad Sci USA 1999, 96:2952-2957.

39. Ramprasad VL, Madhavan J, Murugan S, Sujatha J, Suresh S, Sharma T, Kumaramanickavel G: Retinoblastoma in India: microsatellite analysis and its application in genetic counseling. $\mathrm{Mol}$ Diagn Ther 2007, 11:63-70.

40. Zhang XL, Fu WL, Zhao HX, Zhou LX, Huang JF, Wang JH: Molecular studies of loss of heterozygosity in Chinese sporadic retinoblastoma patients. Clin Chim Acta 2005, 358:75-80.

41. Dublin EA, Patel NK, Gillett CE, Smith P, Peters G, Barnes DM Retinoblastoma and p16 proteins in mammary carcinoma: their relationship to cyclin D1 and histopathological parameters. Int J Cancer 1998, 79:71-75.

42. Gorgoulis VG, Koutroumbi EN, Kotsinas A, Zacharatos P, Markopoulos C, Giannikos L, Kyriakou V, Voulgaris Z, Gogas I, Kittas C Alterations of p16-pRb pathway and chromosome locus 9p2122 in sporadic invasive breast carcinomas. Mol Med 1998, 4:807-822.

43. Perou CM, Sørlie T, Eisen MB, Rijn M van de, Jeffrey SS, Rees CA, Pollack JR, Ross DT, Johnsen H, Akslen LA, Fluge O, Pergamenschikov A, Williams C, Zhu SX, Lonning PE, Borresen-Dale AL, Brown PO, Botstein D: Molecular portraits of human breast tumours. Nature 2000, 406:747-752.

44. Ross DT, Perou CM: A comparison of gene expression signatures from breast tumors and breast tissue derived cell lines. Dis Markers 2001, 17:99-109.

45. Brenner AJ, Stampfer MR, Aldaz CM: Increased $\mathbf{p} 16$ expression with first senescence arrest in human mammary epithelial cells and extended growth capacity with p16 inactivation. Oncogene 1998, 17:199-205.

46. Li Y, Pan J, Li JL, Lee JH, Tunkey C, Saraf K, Garbe JC, Whitley MZ, Jelinsky SA, Stampfer MR, Haney SA: Transcriptional changes associated with breast cancer occur as normal human mammary epithelial cells overcome senescence barriers and become immortalized. Mol Cancer 2007, 6:7.

47. Kotake $Y$, Cao R, Viatour $P$, Sage J, Zhang Y, Xiong Y: pRB family proteins are required for $\mathrm{H} 3 \mathrm{~K} 27$ trimethylation and Polycomb repression complexes binding to and silencing p16INK4alpha tumor suppressor gene. Genes Dev 2007, 21:49-54.

48. Lukas J, Parry D, Aagaard L, Mann DJ, Bartkova J, Strauss M, Peters G, Bartek J: Retinoblastoma-protein-dependent cellcycle inhibition by the tumour suppressor p16. Nature 1995, 375:503-506.

49. Emig R, Magener A, Ehemann V, Meyer A, Stilgenbauer F, Volkmann M, Wallwiener D, Sinn HP: Aberrant cytoplasmic expression of the p16 protein in breast cancer is associated with accelerated tumour proliferation. $\mathrm{Br} J$ Cancer 1998, 78:1661-1668.

50. Hui R, Macmillan RD, Kenny FS, Musgrove EA, Blamey RW, Nicholson RI, Robertson JF, Sutherland RL: INK4a gene expression and methylation in primary breast cancer: overexpression of p16INK4a messenger RNA is a marker of poor prognosis. Clin Cancer Res 2000, 6:2777-2787.

51. Milde-Langosch K, Bamberger AM, Rieck G, Kelp B, Loning T: Overexpression of the $p 16$ cell cycle inhibitor in breast cancer is associated with a more malignant phenotype. Breast Cancer Res Treat 2001, 67:61-70.

52. Grupka NL, Bloom C, Singh M: Expression of retinoblastoma protein in breast cancer metastases to sentinel nodes: evaluation of its role as a marker for the presence of metastases in non-sentinel axillary nodes, and comparison to p16INK4a. Appl Immunohistochem Mol Morphol 2006, 14:63-70.

53. Livasy CA, Perou CM, Karaca G, Cowan DW, Maia D, Jackson S, Tse CK, Nyante S, Millikan RC: Identification of a basal-like subtype of breast ductal carcinoma in situ. Hum Pathol 2007, 38:197-204

54. Derenzini M, Donati G, Mazzini G, Montanaro L, Vici M, Ceccarelli C, Santini D, Taffurelli M, Trere D: Loss of Retinoblastoma Tumor Suppressor Protein Makes Human Breast Cancer Cells More Sensitive to Antimetabolite Exposure. Clin Cancer Res 2008, 14:2199-2209.

55. Carey LA, Dees EC, Sawyer L, Gatti L, Moore DT, Collichio F, Ollila DW, Sartor Cl, Graham ML, Perou CM: The triple negative paradox: primary tumor chemosensitivity of breast cancer subtypes. Clin Cancer Res 2007, 13:2329-2334.

56. Rouzier R, Perou CM, Symmans WF, Ibrahim N, Cristofanilli M, Anderson K, Hess KR, Stec J, Ayers M, Wagner P, Morandi P, Fan 
C, Rabiul I, Ross JS, Hortobagyi GN, Pusztai L: Breast cancer molecular subtypes respond differently to preoperative chemotherapy. Clin Cancer Res 2005, 11:5678-5685.

57. T'Ang A, Varley JM, Chakraborty S, Murphree AL, Fung YK: Structural rearrangement of the retinoblastoma gene in human breast carcinoma. Science 1988, 242:263-266.

58. Varley JM, Armour J, Swallow JE, Jeffreys AJ, Ponder BA, T'Ang A, Fung YK, Brammar WJ, Walker RA: The retinoblastoma gene is frequently altered leading to loss of expression in primary breast tumours. Oncogene 1989, 4:725-729.

59. Kallioniemi A, Kallioniemi OP, Waldman FM, Chen LC, Yu LC, Fung YK, Smith HS, Pinkel D, Gray JW: Detection of retinoblastoma gene copy number in metaphase chromosomes and interphase nuclei by fluorescence in situ hybridization. Cytogenet Cell Genet 1992, 60:190-193.

60. Dimaras H, Khetan V, Halliday W, Orlic M, Prigoda NL, Piovesan B, Marrano P, Corson TW, Eagle RC Jr, Squire JA, Gallie BL: Loss of RB1 induces non-proliferative retinoma: increasing genomic instability correlates with progression to retinoblastoma. Hum Mol Genet 2008, 17:1363-1372.

61. Richter S, Vandezande K, Chen N, Zhang K, Sutherland J, Anderson J, Han L, Panton R, Branco P, Gallie B: Sensitive and efficient detection of RB1 gene mutations enhances care for families with retinoblastoma. Am J Hum Genet 2003, 72:253-269.

62. Valverde JR, Alonso J, Palacios I, Pestana A: RB1 gene mutation up-date, a meta-analysis based on 932 reported mutations available in a searchable database. BMC Genet 2005, 6:53. 